University for Business and Technology in Kosovo

UBT Knowledge Center

Nov 7th, 9:00 AM - 5:00 PM

\title{
Organized Crime Phenomenon Threatening Public Safety and Rule of Law in Kosovo
}

Fatos Haziri
University of Prishtina

Follow this and additional works at: https://knowledgecenter.ubt-uni.net/conference

Part of the Law Commons

\section{Recommended Citation}

Haziri, Fatos, "Organized Crime Phenomenon Threatening Public Safety and Rule of Law in Kosovo" (2015). UBT International Conference. 2.

https://knowledgecenter.ubt-uni.net/conference/2015/all-events/2

This Event is brought to you for free and open access by the Publication and Journals at UBT Knowledge Center. It has been accepted for inclusion in UBT International Conference by an authorized administrator of UBT Knowledge Center. For more information, please contact knowledge.center@ubt-uni.net. 


\title{
Organized Crime Phenomenon Threatening Public Safety and Rule of Law in Kosovo
}

\author{
Fatos Haziri \\ Prishtina University “ Has an Prishtina”
}

\begin{abstract}
Nowadays organized crime is considered as a real threat to the security of any country, but in particular, to the security of countries with fragile democracies that do not have any strength, tradition or experience to effectively deal with it. In this regard, for Balkans, this phenomenon is considered as the main threat to the security of each country and the region in general and in particular for our country Kosovo. Despite the progress achieved, the creation of institutions since 1999 had three transitions; UNMIK period 1999-2008, the declaration of independence on February 17, 2008 and the arrival of new EULEX mission in 2009 that was made to build a new future through integration process in the European Union, in the eyes of the international community our region is still considered quite fragile and challenging. The events of 1990-1999 in former Yugoslavia created great difficulties not only for the new states but also in the actual integration developments that these countries aim not to lose the chance to refute another infamous epithet as "organized crime haven". In this epithet may have doses of exaggeration, but the truth for these last 20 years is that, while all kinds of industries in the region have failed, there is a thriving new "industry", working day and night in full capacity: industry of organized crime.
\end{abstract}

Keywords: What is organized crime? What are the sources? Where is more widespread in the Western Balkans? How can you fight against organized crime? Which are investigative techniques?

\section{Introduction}

In modern time, organized crime is considered as a real threat to the security of any country, but in particular, for the safety of countries with fragile democracies, that have no tradition or ap propriate experience to deal effectively with it. In this respect, in Balkans, this phenomenon is considered as the main threat to the security of each country and generally for the entire region and in particular for our country, Kosovo.

Despite the progress achieved: the process of the creation of institutions since 1999 during which process we had three transitions, that of UNMIK period from 1999 to 2008, declaring the independence on February 17, 2008 and the arrival of new EULEX mission in 2009 that was made to build a new future through integration process in the European Union, in the eyes of the international community our region is still valued highly fragile and challenging.

The events during the years 1990-1999 in the former Yugoslavia created great difficulties not only for the new states but also in current integrating developments, in which these countries intend not to lose a chance to deny another infamous epithet, as "organized crime haven". In this epithet may have doses of exaggeration, but the truth for these last 20 years is that, while all kinds of industries in the region have gone bankrupt, has flourished a "new industry", working day and night in full capacity which is called "organized crime industry". This has made even the perspective of geostrategic assessment to undergo a major shift. Balkan strategic importance now is not seen neither in natural advantages nor in the military advantages, but in the risks that it can export to. Among them, the phenomenon of organized crime is seen as one of the main risks.

For this reason the struggle against it is composed from one of the main directions of international contribution to the strengthening of institutions in the region, but at the same time one of the basic conditions to be met by the governments of these countries to realize the aspiration of integration into the EU and NATO. An assessment of threats and risks from organized crime in Southeastern European countries remains danger and major obstacle to progress, particularly for Kosovo. 
Also according to expert evaluation, organized crime is included among the three main types of threats of our time in the field of public order and safety and its direct impact in the rule of law. Organized crime is also seen as a source of direct feed to these threats, whether it is regional, ethnic conflicts or terrorism. As an illegal activity based on illegal profit, organized crime threatens the stability of the rule of law and threatens and challenges legal and economic foundations of the state. Organized crime, with its focus on economic and financial crime, has become today the highest growing trend component in the world, with a global profit estimated about 1.8 trillion USD per year. While in Southeastern European countries are thousands of companies and banks that are managed by organized crime groups. Balkan countries, except Croatia, loose about 20 - 30\% of annual revenue from organized crime. This empowerment of criminal groups and organized crime is dangerous because they constitute a threat against the state, peace and the tendency of finding a potential partner to international terrorism.

\section{Background of organized crime in Kosovo}

In the last century there were forms of organized crime in the Balkans and in Kosovo. Naturally the question arises how it was possible that within 14 years it was developed at a dizzying speed, so much as it could compete even with the most notorious mafia? The given answers are different, but in particular the analysis and evaluation experts refer to the following factors:

Prolonged transition: With the end of the Cold War, occurred total destruction of social structures and law enforcement, which resulted in a chaotic situation very favorable for the emergence and fast flourishing of phenomena and structures of organized crime.

Lack of tradition and experience in democracy. The Balkans in the 1990s was like Europe in the 1950 s, but with the difference that here lacked political traditions and cultural foundations to build a stable democracy.

Economic development. The privatization of public assets and the transition to a free market economy was accompanied by abusive practices, greater unemployment and extreme poverty. The creation of a European single market brought reduced trade barriers, at the same time for the exercise of unlawful activities.

Smuggling of people. During the 1990s, Balkan countries and Kosovo in particular, were introduced to the migration of larger scale since the years 1955-1966. During the transition, only from Kosovo emigrated ap proximately $30 \%$ of the total population, or $45 \%$ of the workforce. Today there are about 700,000 immigrants, mainly in Germany $(250,000)$, in Switzerland $(150,000)$, in UK 50,000, about 50,000 in Scandinavian countries, in Benelux countries around 50000, around 50000 in Austria, in Italy more than 20000 , in Slovenia and Croatia above 20000 and in other states of the EU and in the USA, Canada, Australia and New Zealand. West was not prepared to understand how far can reach the adventure of people deprived of freedom for a long time, with unmet vital needs, remained within the limits of a dream and a hope.

The geographical position. Geographically, Balkans has been a corridor connecting three continents: Europe, Asia and Africa, and historically has been a increasingly troubled boundary between freedom and oppression, backwardness and development, welfare and poverty. Kosovo is considered a quadrilateral relationship between Belgrade-Thessaloniki and Sofia-Rome.

The advantage of action. Another reason why organized crime has progressed rapidly in our country is the advantage of action to benefit from newly created situation, while the strategies and cooperation among institutions within the state has its difficulties. What it is worth noting is that regional cooperation between law enforcement agencies is extremely slow indicator, but with signs of optimism based on funding and projects of regional mechanisms to improve the existing situation.

\section{Definition}

The UN Convention of 2000 defined it as "a structured group of three or more persons acting in collaboration, to provide, directly or indirectly, a financial or other material benefit".

Key feature of organized crime is illegal acquirement of financial gain, without hesitation to use any illegal action. The drive for profit is the basic reason that dictates the decisions and actions of the greater number of criminal organizations today. Other features are the organization, discipline and 
loyalty among members of the organization, corruption of officials and governors, respect for hierarchy, and the diversity of criminal activities. Organizational survival is also another significant feature of organized crime groups. Ties between members, who are often relatives or the same blood, are created such that all collisions that may endure an individual, organization should succeed and continue the activity.

Participation or organization of organized criminal group under the legislation of the Republic of Kosovo $^{27}$

1. Whoever, with the intent and with knowledge of either the aim and general activity of the organized criminal group or its intention to commit one or more criminal offenses which are punishable by imprisonment of at least four (4) years, actively takes part in the group's criminal activities knowing that such participation will contribute to the achievement of the group's criminal activities, shall be punished by a fine of up to two hundred fifty thousand $(250,000)$ EUR and imprisonment of at least seven (7) years.

2. Whoever organizes, establishes, supervises, manages or directs the activities of an organized criminal group shall be punished by a fine of up to five hundred thousand $(500,000)$ EUR and by imprisonment of at least ten (10) years.

3. When the activities of the organized criminal group provided for in paragraph 1 or 2 of this Article result in death, the perpetrator shall be punished by a fine of up to five hundred thousand $(500,000)$ EUR and by imprisonment of at least ten (10) years or lifelong imprisonment.

4. The court may reduce the punishment of a member of an organized criminal group who, before the organized criminal group has committed a criminal offense reports to the police or prosecutor the existence, formation and information of the organized criminal group in sufficient detail to allow the arrest or the prosecution of such group.

5. For the purposes of Article, "actively takes part" includes, but is not limited to, the provision of information or material means, the recruitment of new members and all forms of financing of the group's activities.

Experts describe organized crime groups from Kosovo with the following features:

- Homogeneous, ready to get in touch and cooperate with other criminal organizations and to open new areas of crime.

- $\quad$ Specialized in drug trafficking, human trafficking and people smuggling.

- $\quad$ Less sophisticated, less cautious, but with a tendency to use violence and willing to use firearms to overcome the obstacles that come along criminal activities.

- $\quad$ Organizations do not claim to be alone in the territory in which they operate. With the principle that "there is room for everyone," operating several organization in a territory, with mutual respect, avoiding collision.

- $\quad$ They do not have vertical structure or a managing dome, but they operate "each on its own".

- The members of criminal groups often change their boss, passing from one group to another.

- $\quad$ In the West, in many cases, are organized on the basis of the towns they come from.

- In aspect of money circulation, it is generally preferred "cash" and not through banking channels.

- $\quad$ Although during telephone conversations are used nicknames, they are not so cautious and often this was the cause of their discovery.

\section{Types of organized crime in Kosovo.}

Criminal organizations cannot give up from goal of quick profits and dominance in economic and public life. They are involved in many areas of criminal activity ranging from drug trafficking, human trafficking, goods trafficking (weapons, stolen cars, cigarettes, etc.), as well as other activities of financial crimes, such as fraud, counterfeiting of coins and money laundering.

Drug trafficking, human smuggling and trafficking. For criminal groups in Kosovo this field is a "paradise" for criminal profits, phenomena that undermine society and rattle political, economic and

${ }^{27}$ More specifically, the provisions of the Criminal Code, Chapter XXIV, Organized crime, Article 283 
social stability in Kosovo. Besides weak structures and the lack of experience of state bodies and law enforcement agencies, Kosovo was affected by this phenomenon because of the geographical position, as the main thoroughfare, linking drug manufacturers in the East with its customers in the West without excluding the impact of migration of the Kosovo citizens. Recently, special place has the activity of people smuggling directly affected by the so-called "Arab spring" especially with the Syrian conflict where criminal groups are finding themselves in cooperation throughout the region dividing spheres of geostrategic interest ${ }^{28}$.

In concept of drug and human trafficking, besides illegal immigration, exploitation for profit is also included, mostly of women and children ${ }^{29}$. According to a UN report in April 2006, this phenomenon has affected almost every country of the world. There were identified 127 countries of origin and 137 countries of destination. Kosovo is ranked as the country of origin and destination with high human trafficking, but also as a transit country. Victims are mostly women, girls and children, "tool" of prostitution and trafficking industry.

In the Balkans, an entire criminal infrastructure has been established and functioning, that is in control of the whole process of human trafficking, in chain system, from recruitment countries, to a certain place $^{30 .}$

Albanian criminal groups are quite advanced in this field and have built networks across Western Europe. Albanian traffickers are known to use violence and talent to deceive their victims, by including for this purpose the female associate or even offering fake marriages. Money laundering is the basic mechanism of recycling all kinds of organized crime. Essentially, the aim is to disguise the criminal nature of profits and to increase revenue to fund criminal activities in new areas. Like the laundries of Al Capone era, any criminal gang has a legitimate business as a facade. Organized crime bosses cannot resist the temptation to make a luxurious life, to demonstrate the power and occupy key positions in the social hierarchy.

Quote from a report of WSJ journalist: When you are in the center of the Pristina, you find it difficult to believe that you are in the poorest country of Europe. On one hand frowning faces, stress and poverty and in the other hand you see luxury shops and villas and teens that drive expensive BMWs and Mercedes. This ostentatious wealth comes from organized crime.

It is considered that informal economy is flourishing in Kosovo, especially in the northern part where criminal groups have exploited political problems and the lack of rule of law to turn that area into oasis and refuge for criminal groups with little or almost no banking activity and all criminal activity is considered to have the nature of money laundering.

Financial crime and money laundering are often the main tools of corruption, in public institutions as well as in private activity.

When criminal profit manages to gain the status of a pure benefit, not does this only cover a committed crime, but also opens the way for a new crime. When criminals appear as gentlemen with white collars and with the help of money aim for position in the top of the social hierarchy, the normal course of development of a society is severely distorted and the social equilibrium is shaken. Another even greater risk is that sophisticated financial crimes and money laundering poses tendency to be used more and more to finance terrorism.

Because money laundering is one of the basic links to organized crime recycling, for state bodies of law enforcement, the fight against this phenomenon is one of the key points to win the battle, which begins with a simple question at the bank counter or in the form of property declaration: "Sir, where is this money earned?"

This battle has already started but I think it will be painful and with the consequences for society of Kosovo.

\footnotetext{
${ }^{28}$ It is deemed that by buying one gram of heroin in Afghanistan for 1 USD and by selling it for 100 USD in Western Europe, Balkan drug cartels earn a mind blowing profit, which experts estimate to be around $\$ 2.5$ billion a year.

${ }^{29}$ After drug industry, the second largest industry in the world is prostitution, with a global annual profit of around \$7-10 billion.

${ }^{30}$ Figures show that out of 700,000 of annual trafficking victims in the world, 200,000 are transported from the Balkans. $70 \%$ of women working in the so-called massage center, and $80 \%$ of London's prostitutes are from the Balkans and Baltic countries. Profit of gangs from this traffic reaches 950 million euro. According to press information, only one bar in Macedonia that deals with trafficking of girls wins between 1000 to 15,000 euro in a single night.
} 


\section{Application of covert and technical measures of investigation}

A major change in the Code of Criminal Procedure has come late in the legislative process at the request of European Union experts for data protection. Articles 84-100 regulate the use of covert and technical measures of investigation. They can be applied before or after authorization of criminal investigations, whether the name of the suspect is known or not. However, in order to meet European Union standards, all should be based on a court order. Therefore, pursuant to Article 91 these intrusive measures include:

- Covert observation with photography or video;

- Covert monitoring of conversations in public places;

- Control of mail shipments;

- Undercover investigation:

- Recording of phone calls;

- Photo or video observation in private places;

- Covert monitoring of conversations in private places;

- Interception of telecommunications: including text messages and other electronic messages;

- Interception of communications via computer network;

- Controlled delivery of mail shipments;

- The use of tools for monitoring the whereabouts;

- Simulated purchase of an item;

- Simulation of corruption offense; and

- Disclosure of financial data.

European Union practices allow the prosecutor to issue a temporary order for any of these measures until the court confirms the order within a reasonably short time. Therefore, in Article 91 (1), the state prosecutor may issue temporary orders only in emergency cases when delays would jeopardize the investigation or the safety and life of the victim, witness, informant or their family members. There is a lower standard for investigations of money laundering or offenses under Chapter XXIV (Organized crime) or Chapter XXXIV (Corruption) of the Criminal Code. When these criminal acts are committed, the state prosecutor may issue a temporary order "in necessary cases" where the delay could harm the investigation or the life and safety of the victim, witness, informant or their family member. In such cases, the disclosure of financial data, for example, may require quick orders for many banks with the purpose of searching or freezing of assets. The court may confirm the interim order within three days to determine the legality of his writing, ex officio. Under Article 92 (1) (3), the order must be supported by the sound probability, while in the previous Code of Criminal Procedure, intrusive measures could be supported with suspicion.

This leaves unanswered the question of whether the evidence would to be acceptable, if they were collected by a provisional order of the prosecutor, but not confirmed by the court. Article 97 (1) clearly states that the evidence is taken through such measures would be unacceptable if the order or its implementation have been unlawful. Under Article 97 (3), defense attorney can challenge the acceptability of those evidences after the indictment and the single judge court or the presiding judge of the case will decide on the exclusion or not of those proofs.

Another major change is in Article 96. Earlier, someone who is mistakenly made the subject of covert measures could require correction of that action before the District Court.

Measures for the protection of data require a greater extent of notification prescribed in Article 96 (4). If there was executed a secret or technical measure, more people should be notified: the person who is the target, the other persons who are greatly affected and private persons and facilities that are affected. Notice to persons who are targeted and to the affected persons, should be done much earlier than in the previous code. According to Article 96 (5), the notification should take place as soon as without endangering the purpose of the investigation, the life, physical integrity and personal liberty of another or significant assets. Those persons may challenge the order for covert and technical measures at the basic court and may appeal the court's decision to the Appeal Court.

These measures for data protection are not optional. Under Article 96 (2), only after the affected parties have received notice of covert measures under Article 96 (5) the decisions and documents relating to these measures can be added to the case file. This raises concerns regarding the use and admissibility of documents arising from these covert and technical measures. Can they be used to seek court orders or to be used during the investigation, or is this limitation narrower? Also, it can be read in the literature regarding the prevention of use of evidence resulting from application of covert 
measures to support an indictment until notification of affected parties. It is also not clear how this will work with an ongoing investigation if a person has been willing to plead guilty and cooperate.

Practitioners should take into account the definitions in article 19. Most investigative actions should be based on reasonable suspicion, grounded cause of sound probability. These are expressions of the previous code of criminal procedure, but which are defined in the new code. To meet the reasonable suspicion, for example, Article 19 (8) states that the prosecut or must have "knowledge of information that would convince an objective observer that a criminal offence has occurred is occurring or there is a substantial likelihood that one will occur and the person concerned is substantially likely to have committed the offence".

Practitioners should take into account the definitions in article 19. Most investigative actions should be based on reasonable suspicion, grounded cause of sound probability. These are expressions of the previous code of criminal procedure, but which are defined in the new code. To meet the reasonable suspicion, for example, Article 19 (8) states that the prosecutor must have "knowledge of information that would convince an objective observer that a criminal act has occurred, is occurring or is highly likely to occur and that the person concerned may commit or may have committed the offense". Standard of "objective observer" requires the prosecutor not to see whether he or she is self-convinced, but whether most people would be convinced from that information. It also does not require possession of admissible evidence, but only the prosecutor to have knowledge of the information. Definitions for grounded suspicion and grounded cause require from the prosecutor to possess "articulable evidence", which means that he or she should be able to describe the supporting evidence for grounded suspicion or grounded cause. These three standards - reasonable doubt, grounded suspicion and grounded cause - do not require that from prosecutor to have evidence that is admissible, but only that he or she has supporting information or evidence.

On the other hand the standard of "sound probability" is higher and is defined in article 19 (1) (11). This is standard to justify intrusion in the privacy of the person, such as medical check or examination, and does not require the prosecutor to have admissible evidence. Also, Article 19 (1) (12) defines "well-grounded suspicion," that is standard for filing an indictment by the prosecutor. This requires the prosecutor to possess "admissible evidence that would convince an objective observer that an offense has occurred and that it is committed by the defendant."

For example, the prosecutor issued a provisional order for interception of telephone messages. One of messages says that drugs will be sold in a bar in city of Gjilan in a week. After three days, the court refuses to confirm the provisional order issued by the prosecutor and does confirm the order ex officio as a lawful order. If the prosecutor asked the court issuing the order to simulate drug purchase at the bar in Gjilan, demand will be based on evidence that were not admissible (the telephone message). Under Article 19 (1) (11), it would not be a sufficient basis for "sound probability" but it would be sufficient for grounded suspicion. However, under Article 92 (1) (3), an order for covert and technical measures should be based on sound probability, that means that the prosecutor should have admissible evidence. Therefore, the court should not accept the request for simulated purchase unless the prosecutor possesses other admissible evidence supporting that claim.

\section{Investigation phase}

If during the initial stages it becomes clear that the offense has occurred and the perpetrator is identified, or that there is a need for covert and technical measures of investigation, in that case the state prosecutor will take over the above investigations. Articles 73-83 require from the police, public entities or individuals to present criminal charges to the state prosecut or, who either dismisses them, requires more information, or begins a criminal investigation. Articles 84-100 regulate the appliance of covert and technical measures of investigation, which can be applied before or after the formal authorization of criminal investigations.

If the state prosecutor initially has sufficient evidence by the police, the injured party or any other source, article 101 allows him to immediately file the indictment. The standard for indictment is that the state prosecutor has evidence to support the well-grounded suspicion that a criminal offense occurred. This standard is set out in Article 101 (2) and Article 240. The defendant can challenge an indictment under Article 250 if it is not based on well-grounded suspicion. Therefore, if there is reasonable suspicion only for the criminal offense but still insufficient for an indictment, the state prosecutor can initiate investigation phase, in accordance with Articles 102-104. At any stage, the 
defendant may plead guilty in accordance with Article 233. State Prosecutor shall decide to initiate the investigation in accordance with Article 103. He/she can still issue order or require from the court to issue order for covert and technical measures of investigation pursuant to Articles 84-100, even after the initiation of investigations. The decision must be issued by the appropriate court, and may include a request for a search warrant under Article 105, or for asset seizure pursuant to Chapter XVIII. The prosecutor may also issue a decision to freeze assets pursuant to Chapter XVII.

\section{Conclusions}

Organized crime is a primary problem in the Republic of Kosovo and constitutes a serious impediment to national security. Its negative impact is felt in all fields: political, economic, social and technological.

1. Politically, organized crime groups can manipulate the political sy stem trying to "buy" power, as in the executive power structures as well as those of law enforcement. This results in disrespect of laws accepted in democratic systems, the lack of stability in the country and the loss of people's confidence in state institutions.

2. In the economic field, organized crime brings degradation of systems and legal practices of businesses. By creating income from money laundered by organized crime groups and their assets in legitimate business market, the legitimate business is compromised severely.

3. The fear that organized crime brings to people is the first and the heaviest impact from the social point of view. Fear leads to lack of trust in the political system and law enforcement.

4. Prospects and challenges: Success in the fight against organized crime is achieved: by improving relevant legislation; rise the number and strengthen the structures that are involved in the fight against organized crime (personnel and their professional skills); by strengthening cooperation with internal and external agencies, institutions and other organizations of law enforcement and, by increasing the level of public awareness.

\section{Bibliography}

1. FBI information on Balkan Organization Crime.

2. FBI-Albanian Mobsters "New Mafia"

3. The Independent - "Gun Gangs of the Capital".

4. Book on Public Security on Police State (year 2009).

5. Transnational Organized Crime - The UN Convention against Transnational Crime books.google.com/organized crime and corruption in the East Southern Europe

6. P. Gounev and T. Bezlov, "Examining the Links between Organized Crime and Corruption", Center for the Study of Democracy (CSD), 2010.

7. United Nations Report "On the Impact of Organized Criminal Activities at Large", New York.

8. 2010 European Union Organized Crime Report (EUROPOL).

9. The National Security Strategy of the Republic of Kosovo.

10. Shelley, Professor and Director/Transnational Crime and Corruption Center American University.

11. Organized crime poses a threat to European democracy. A report of the Council of Europe, 2005.

12. Organized Crime in the Balkans Speech by The Rt Hon Chris Patten, CH U Conference on Organized Crime, London 25/11/02

13. Albania and Kosovo cooperate in the fight against organized crime by Erlis Selimaj for Southeast European Times in Tirana, 13/01/06.

\section{Internet websites:}

1. www.mafia-news.com

2. www.unodc.org/Greater-Stability-In-The-Balkans-Is-Lowering-Crime

3. www.wilsoncenter.org/Combating-Organized-Crime-In-The-Balkans

4. www.fbi.gov / Organized Crime in the Balkans

5. www.analyst-network.com/Article-The new international organized crime in the Balkans 
International Conference on Law, Nov 2015

6. www.secicenter.org/Countermeasures-in-the-balkans-against-organized-crime

7. www.friendsofeurope.org

8. www.scoop project.org.uk/organized-crime-and-corruption-threaten-human-securityinthebalkans - Frank Shanty, Patit Paban Mishra - 2008 Law. 